\title{
A Very Rare Cause of Abdominal Pain: Spleen Infarction
}

\author{
Karın Ağrısının Nadir Bir Nedeni: Dalak İnfarktı
}

\author{
Akdeniz YS ${ }^{1}$, Aydın $\mathbf{Y}^{2}$, İkizceli İ $\dot{1}^{1}$ Bavunoğlu I ${ }^{3}$ \\ 1-İstanbul Üniversitesi-Cerrahpaşa, Cerrahpaşa Tıp Fakültesi, Acil Tıp Anabilim Dalı, İstanbul, Türkiye. 2-T.C. Sağlı Bakanlığı, İstanbul \\ Silivri Devlet Hastanesi, Acil Servis, İstanbul, Türkiye. 3-İstanbul Üniversitesi-Cerrahpaşa, Cerrahpaşa Tıp Fakültesi, İç Hastalıkları Anabilim \\ Dal1, İstanbul, Türkiye.
}

\begin{abstract}
Spleen infarction is a rare, uncommon clinical condition that is difficult to diagnose unless clinical suspicion is present. It is mostly due to thromboembolism or hematologic disease. It usually regresses with medical treatment without surgical intervention. A small number of case reports are available in the literature, and the diagnosis rarely comes into mind, especially in the emergency department. We wanted to discuss a case with atrial fibrillation and splenic infarction presenting to the emergency department with abdominal pain. ÖZET

Dalak infarktı özellikli bulguları olmayan, klinik şüphe olmadı̆̆ı sürece tanısı çok zor konulan ve nadir görülen sessiz bir klinik durumdur. Çoğunlukla sebebi tromboemboli veya hematolojik bir hastallktır. Genelde cerrahi müdahale gerektirmeden medikal tedavi ile tablo geriler. Literatürde sayılı olgu bildirimleri mevcuttur ve tanı özellikle acil serviste nadiren akla gelip konulabilir. Biz acil servise karın ağrisı șikayeti ile başvuran, atriyal fibrilasyonu olan ve dalak infarktı saptanan olgumuzu literatür taraması eşliğinde tartışmak istedik.
\end{abstract}

Key Words:

Abdominal pain, Atrial Fibrillation, Splenic infarction, Thromboembolism.

Anahtar Kelimeler:

Karın Ağrısı, Atriyal Fibrilasyon, Dalak infarktı, Tromboemboli.

\section{GíRiş}

Atrial fibrilasyon (AF) gibi ritim bozukluğu olan hastalarda tromboembolik komplikasyonlar ortaya çıkabilir (1). Bunlardan çok nadir saptananlarından biri klinik bulguları özellikli olmayan, sessiz ve bazen ölümcül seyredebilen dalak infarktıdır (2). Bu terim dalakta damar tıkanıklığı veya başka sebepler sonrası gelişen dolaşım bozukluğu sonucu doku nekrozu oluşmasını ifade eder (2).

Dalak infarktı tanısı çok zor konulan bir klinik durumdur (3). Genellikle tanı ölüm sonrası otopside saptanır (4). Olguların sadece \%10 kadarında klinik şüphe varlığı olduğu bildirilmiştir (1). En sık görülen şikâyet ve bulgular karın ağrısı, sol üst kadran hassasiyeti, ateş ve lökositozdur (1-8). İntravenöz (IV) kontrastlı bilgisayarlı batın tomografisi (batın BT) infarkt alanını göstermede kullanılan en pratik yöntemdir. On yıllık dalak infarktlarının incelendiği bir çalışmada ultrasonografinin (USG) olguların sadece \%18'inde tanısal olduğu bildirilmiştir (4).

Dalak infarktı en sık orak hücreli anemi, polisitemia vera, protein $\mathrm{C}$ ve $\mathrm{S}$ eksikliği gibi hematolojik hastalıklar varlığında görülür (4-7). Sonrasında tromboembolik durumlarda, bağ dokusu hastalıklarında, daha nadir olarak septik emboliye sebep olabilecek endokarditlerde ve çok nadir olarak da dalak enflamasyonuna sebep olan plasmodium, brucella ve tüberküloz gibi enfeksiyonlarda ve Wegener Granülomatozisinde saptanmıştır (5,8-10). Biz de atrial fibrilasyonu olan ve dalak infarktı tespit ettiğimiz bir olguyu literatürü değerlendirerek tartı̧̧̧ak istedik.

\section{OLGU}

67 yaşında bayan hasta 2 gündür devam eden bulantı kusmanın eşlik ettiği, devaml, künt karakterde, herhangi bir yere yansıması olmayan, göbek çevresinde karın ağrısı şikâyeti ile acil servisimize başvurdu. 15 yıldır bilinen kronik atrial fibrilasyon, 5 yıl önce yapılmış koroner arter angiografisi, 5 ay önce sol bacakta akut arteryel trombüs nedeniyle geçirilmiş embolektomi öyküsü olan hasta antiagregan (asetilsalisilik asit $100 \mathrm{mg} 1 * 1$ ) tedavisi almaktayd 1 . Fizik muayenede genel durumu orta, bilinç açık, oryante ve koopere, kan basınc1 130/80 mmHg, nabzi: $80 / \mathrm{dk}$, solunum sayısı $30 / \mathrm{dk}$, ateşi $37.3{ }^{\circ} \mathrm{C}$ idi. Kalp ritmi düzensiz ve taşikardik olan hastanın batın muayenesinde yaygın hassasiyet dışında patolojik bulgu tespit edilmedi. Rektal tuşede normal gayta saptandı. Laboratuar tetkiklerinde lökositoz, LDH yüksekliği ve CRP yüksekliği dışında patoloji tespit edilmedi (Tablo 1). Çekilen elektrokardiyografisinde atrial fibrilasyon ve sağ dal bloğu, ayakta direkt batın grafisinde (ADBG) yaygın ince ve kalın bağırsak gazı görülen hastanın tüm batın ultrasonografisinde patolojik bir bulgu saptanmadı (Resim 1). Mezenter embolisi şüphesiyle çekilen IV kontrastl anteriyorunda yaygın hipodens alan, sol böbrekte posteriyorda kronik infarkta bağlı kortikal atrofi ve perisplenik alanda efüzyon tespit edildi (Resim 2ab). Aksiyel planda kontrastlı toraks bilgisayarlı tomografisinde de sol atriyum normalden büyük ve sağ atriyum anteriyor duvarda şüpheli hipodens (trombüs?) alan mevcuttu (Resim 2c). Hasta dalak infarktı tanısıyla 
Tablo 1: Hastanın acil başvurusundaki laboratuvar bulguları

\begin{tabular}{ll}
\hline Tetkik & Sonuç \\
\hline Beyaz küre & $15980 / \mathrm{mm} 3$ \\
Hemoglobin & $13.5 \mathrm{~g} / \mathrm{dL}$ \\
Hematokrit & $40.6 \%$ \\
Platelet & $222000 / \mathrm{mm} 3$ \\
PT & $15.3 /$ saniye \\
PTT & $42.7 /$ saniye \\
LDH & $577 \mathrm{U} / \mathrm{L}$ \\
CRP & $300 \mathrm{mg} / \mathrm{L}$ \\
\hline
\end{tabular}

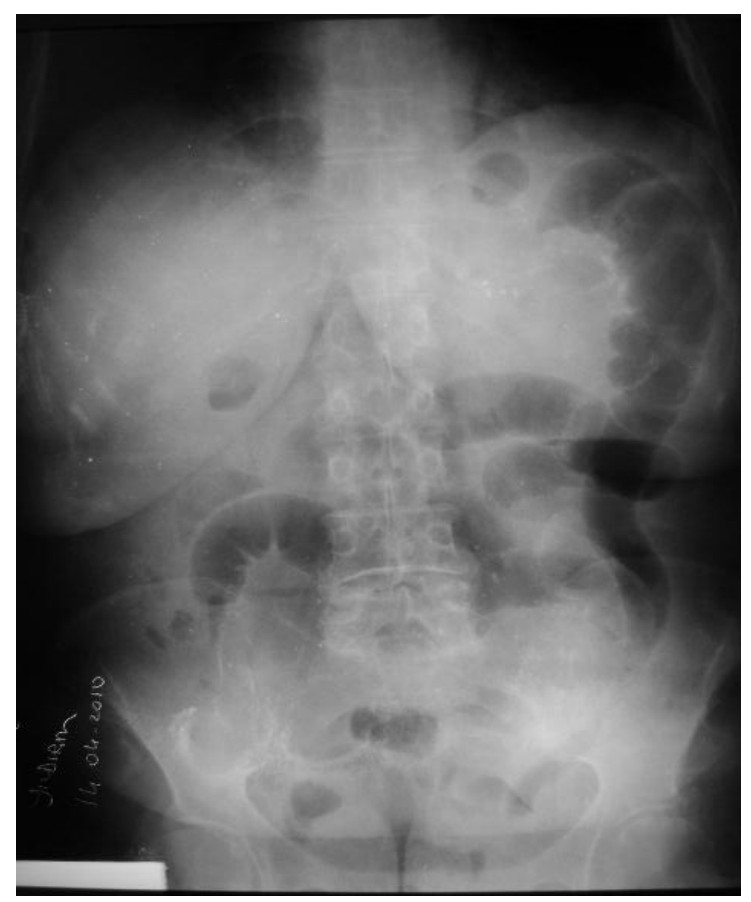

Resim 1: Ayakta direk karın grafisinde ince ve kalın barsağa ait gaz görüntüleri genel cerrahi servisine yatırıldı. Semptomatik tedavi sonrası genel durumu düzelen hasta poliklinik kontrolü önerilerek taburcu edilmiştir.

\section{TARTIŞMA}

Dalak infarktı etyolojisinde birçok faktörün yer aldığ 1 , dalak parankiminde dolaşım bozukluğu veya hipoksi sebebiyle hücrelerde nekrozun geliştiği geri dönüşümsüz bir klinik tablodur (2).

Dalak infarktüsü nedenleri arasında emboli \%38, hematolojik hastalıklar \%29, splenik vasküler hastalıklar $\% 6$, anatomik bozukluklar $\% 5$ ve bağ dokusu hastalıkları sayılmaktadır (2,5). Daha güncel bazı çalışmalarda en s1k neden hematolojik hastalıklar olarak bulunmuştur $(1,2,5)$. Emboli nedeni olarak da infektif endokardit, atrial fibrilasyon ve kardiyak cerrahi sonras1 komplikasyon sayılmaktadır $(4,5)$. Bizim hastamızda da atrial fibrilasyon mevcut olup toraks bilgisayarlı tomografisinde sağ atrium geniş ve içinde dolum defekti mevcut olduğundan dolayı infarktüsün nedeninin atrial fibrilasyona bağlı emboli olduğu düşünülmüştür.

Orak hücre hastalığı gibi infiltratif hematolojik hastalıklarda hipoksi ve asidoz varlığında kristalleşen ve çöken anormal hücreler dolaşımı bozar ve infarkt gelişir (2). $\mathrm{Bu}$ tip az sayıda olgu bildirimi yapılmıştır $(2,5)$. Protein $\mathrm{C}$, protein $\mathrm{S}$ eksikliği, faktör $\mathrm{V}$ leiden mutasyonu, protrombin A mutasyonu, antifosfolipid sendromu, maligniteler gibi hiperkoagülabiliteye sebep olan hastalıkların dalak infarktına sebep olabileceği bildirilmiştir $(2,4,5)$. Bizim hastamızda bu klinik durumlar, periferik yayma ve ilgili hastalıklara özgü koagülopati testleri normal düzeyde olduğundan ekarte edilmiştir.

Çoğu çalışmada en sık başvuru şikâyeti sol üst kadranda olan karın ağrısıdır (4-7). En sık muayene bulgusu ise sol üst kadran hassasiyetidir (4-6). Ağrının bir haftadan kısa veya uzun olmasının eşit düzeyde görüldüğü ayrıca ateş, titreme, bulantı ve kusmanın eşlik edebileceği bildirilmiştir $(2,4,6)$. Bizim hastamızda batında yaygın hassasiyet mevcuttu ve bulantı ve kusmanın eşlik ettiği göbek çevresinde iki gündür olan ağrı şikâyeti vardı.

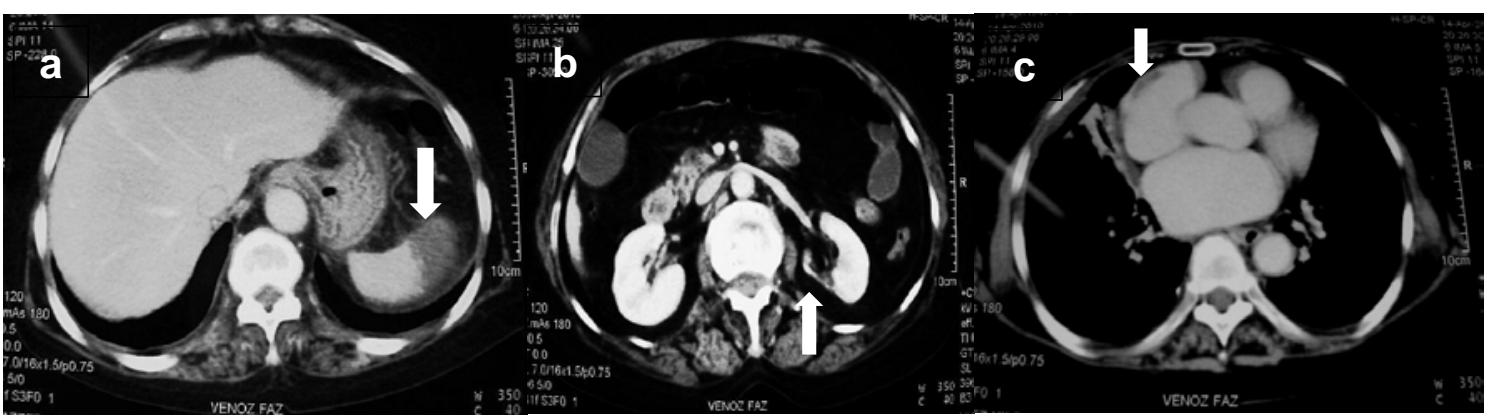

Resim 2: Hastanın batın BT kesitleri

a)Aksiyel planda kontrastlı batın BT de venöz fazda dalak anteriyorunda infarkt ile uyumlu hipodens alan (beyaz ok) izleniyor. b)Aksiyel planda kontrastlı batı BTde süperiyor mezenterik arter ve ven açık. Sol böbrekte posteriyorda kronik enfarkta bağlı kortikal atrofi (beyaz ok) mevcut. c) Aksiyel planda kontrastlı toraks BT de sol atriyum normalden büyük ve sağ atriyum anteriyor duvarda şüpheli hipodens alan (beyaz ok) mevcut. Sağ akciğer orta lobda atelektatik alan izleniyor 
Hastaların laboratuar incelemelerinde \%53' ünde anemi, \%49' unda lökositoz ve \%7' sinde trombositoz olduğu ve ayrica periferik yaymada Howell Jolly cisimciklerinin görülebileceği bildirilmiştir (2,5). Ayrıca LDH ve CRP yüksekliği de görülmüştür (4). Bizim hastamızda da lökosit, LDH ve CRP yüksekliği mevcuttu. Ancak anemi ve trombositoz tespit edilmedi.

Görüntülemede ADBG' de masif infarkt varlığında sol üst kadrana uyan bölgede gaz gölgeleri veya hava-sıv1 seviyeleri görülebileceği bununla beraber batın USG' nin ise erken dönemde bulgu vermediği ancak 24 saatten sonra demarkasyon hattı oluşumu ile tanıyı destekleyebileceği bildirilmiştir $(2,5,7)$. USG' nin infarkt tanısı alan hastaların sadece \%18'inde tanı koydurucu olduğunu söyleyen 10 yıllık infarkt hastalarını kapsayan bir çalışma mevcuttur (4). Bizim hastamızda ADBG' de sol tarafta daha fazla olacak şekilde yaygın gaz gölgeleri vardı. Batın USG' de ise dalakta patoloji saptanmamıştı.

Emboli düşünülen vakalarda batın BT'de iyi sınırlı kontrast tutmayan hipodens alan görüntüsü $\% 75$ tanı koydurucudur $(2,5,6)$. Bu hipodens alan genelde kama şeklindedir ve problemli damar bölgesini gösterir $(1,6,7)$. Bizim hastamızda da I.V. kontrastlı batın BT sonrası dalak infarktı tanısı konmuştur.

Literatürde dalak infarktı tanısı konulduktan sonra akut tablonun semptomatik tedaviyle 7-14 gün arasında gerileyeceği gösterilmiştir $(2,5,6)$. Ancak hastaların \%20 kadarında dalak absesi, subkapsüler kanama, rüptür ve pseudokist oluşumu gibi istenmeyen durumlar ortaya çıkabilir $(1,2,5,6)$. Bu tip durumlarda, sepsiste, septik embolide ve semptomları sürekli tekrarlayan hastalarda splenektomi gereklidir $(1,2,5,6)$. Genelde hastaların $1 / 3$ ' ünün splenektomi ihtiyacı geliştiği bildirilmiştir $(2,5)$.Bizim hastamızın yatırıldığ 1 cerrahi servisinde semptomatik tedavi sonrası ağrıları azalmış, genel durumu düzelmiş ve cerrahi müdahaleye gerek kalmadan taburcu edilmiştir.

\section{SONUÇ}

Dalak infarktı nadir görülen bir durumdur, ancak acil servise karın ağrısı ile başvuran ve özgeçmişinde atrial fibrilasyon veya tromboemboli hikâyesi olan hastaların ayırıcı tanısında mutlaka düşünülmelidir. Her ne kadar dalak infarktı çoğunlukla ciddi komplikasyonlara sebep olmadan kendi kendine gerileyebilen klinik bir tablo olsa da gerekli tedavi verilmediğinde ölümcül de seyredebilir (1). Hastalık diğer akut karın tablolarını taklit ettiği için ayırımı zordur. Klinik şüphe elimizdeki en kuvvetli silahtır. Bu yüzden acil serviste özellikle tanısı belli olmayan sessiz ve özelliksiz karın ağrısı vakalarında ayırıcı tanıda dalak infarktı da düşünülmelidir.

Çıkar çatışması

Tüm yazarlar çıkar çatışması olmadığını beyan eder.

\section{KAYNAKLAR}

1. Menke J, Lüthje L, Kastrup A ve ark. Tromboembolism in Atrial Fibrilation. Am J Cardiol 2010; 105:502-510.

2. Yalçın M, Yılmaz H, Kırcı A ve ark. A Case of Splenic Infarction Developing Atrial Fibrillation. JAEMCR 2014; 5: 141-3.

3. Dursun ZB, Demiraslan H, Çelik İ ve ark. A Case of Splenic İnfarction Associated with Brucellosis which Resolved with Antimicrobial Treatment. JMID 2012; 2 (4): 168-170.

4. Antopolsky M, Hiller N, Salameh et al. Splenic Infarction: 10 Years of Experience. Am J Emerg Med 2009; 27: $262-265$.

5. Hatipoğlu A, Karakaya K, Karagülle E ve ark. Nadir Görülen bir Akut Karın Tablosu: Splenik İnfarkt "Case Report”. Ulus Travma Derg 2010; 6 (3): 228-230.

6. Babaoğlu H, Sahna Ö, Çağlayan K ve ark. Sol Üst Kadranda Ağrı: Splenik İnfarkt? Bozok Tıp Derg. 2012,2:71-74

7. Kabaoglu B, Coşkun H, Yanar H ve ark. A Rare Case of Splenic İnfarct Presenting with Acute Abdomınal Pain due to Polyarteritis Nodosa: Case Report and Review of the Literature. Ulus Travma Derg 2005: 242-247.

8. Arslan K, Cesur S, Yüksekkaya E ve ark. Bruselloza Bağlı Dalak İnfarktı Gelişen Olgu. Ortadoğu Tıp Derg 2018 ; 10 (1): 77-80.

9. Soysal D, Yersal Ö, Karakuş V ve ark. Wegener Granülomatozisi Seyrinde Dalak İnfarktı. Turkiye Klinikleri J Med Sci 2007; $27: 783-787$.

10. Turan H, Togan T, Oğuz H ve ark. Plasmodium falciparum İnfeksiyonu Sonrası Gelişen Bir Splenik İnfarkt. Turkiye Parazitol Derg 2015; 39: $60-62$. 